\title{
Deserving citizenship?
}

\section{Exploring migrants' experiences of the 'citizenship test' process in the United Kingdom}

\begin{abstract}
Since the early 2000s several European countries have introduced language and citizenship tests as new requirements for access to long-term residence or naturalization. The content of citizenship tests has been often presented as exclusionary in nature, in particular as it is based on the idea that access to citizenship has to be 'deserved'. In this paper, we aim to explore the citizenship tests 'from below', through the focus on the experience of migrants who prepare and take the 'Life in the UK' test, and with particular reference to how they relate to the idea of 'deservingness'. Through a set of in-depth interviews with migrants in two different cities (Leicester and London), we show that many of them use narratives in which they distinguish between the 'deserving citizens' and the 'undeserving Others' when they reflect upon their experience of becoming citizens. In so doing, they negotiate new hierarchies of inclusion into and exclusion from citizenship, which reflect broader neo-liberal and ethos-based conceptions of citizenship.
\end{abstract}




\section{Introduction}

In 2005, in the context of intense debates on diversity and integration in the UK, the Labour government changed the process through which migrants become British citizens. In order to "foster the 'right kind' of integration" (McGregor and Bailey, 2012: 366), it required migrants to demonstrate their ability to speak and read English, to take a citizenship test (the Life in the UK Test), and to attend a ceremony. ${ }^{1}$ Migrants who want to become British citizens now have to undertake a "journey" (Home Office, 2011) that begins with the application for citizenship and ends with receiving the British passport. At the core of the "journey" were the language test and the citizenship test in which candidates have to answer a set of questions in order to prove their knowledge of British "history, culture and traditions" (Kostakopoulou, 2010; Schinkel and Van Houdt, 2010). These new requirements have been analysed as a new paradigm in British immigration and integration policies (Joppke, 2007; Ryan, 2008; Vink and deGroot, 2010). They crystallize a perceived failure of multiculturalism (Modood, 2012) and show a

move towards a more assimilationist model that takes the form of a "culturalisation of citizenship" (Tonkens et al., 2010) as it implies that access to citizenship should be based on cultural dimensions such as language or the knowledge of "British values".

These new requirements are not unique to the UK: similar tests and ceremonies were introduced in several European countries in the 2000s. Recent empirical studies that have explored how these requirements are experienced by migrants show converging findings. In particular, the literature shows that the nature and 
the content of these tests translate into specific strategies of self-presentation on the part of migrants when they anticipate expectations of the law and of institutional actors. Migrants who go through naturalization processes anticipate what they have to do to prove they 'deserve' citizenship, and they present themselves accordingly when they interact with state representatives (Chauvin and Garcés-Mascarenas, 2014; Fassin and Mazouz, 2007; Menjivar and Lakhani, 2016).

In this article, we explore how migrants who go through the citizenship test "journey" relate to the idea of deservingness, looking in particular at a dimension that has been less explored in the literature: the construction of a distinction within the process between 'deserving' and 'undeserving' migrants primarily by migrants. We draw on Fassin and Mazouz (2007) and other studies that have focused on the notion of deservingness in the relation between migrants and state authorities $^{2}$ to explore more specifically how this injunction to deservingness, a key value at the core of the citizenship test, defines a set of specific characteristics of the 'deserving citizen' and separates this figure from the 'undeserving Other'. We explore more precisely the nature of the symbolic boundaries that are constructed by migrants themselves when they refer to the idea of deservingness. In doing so, we consider processes that go beyond the strategies of presentation of migrants when they face state representatives. Following Menjivar and Lakhani (2016: 1821), we aim to go "beyond how immigrants have learned to present themselves in an application" to explore whether and how migrants relate to the notion of deservingness beyond their 'strategic' interaction with public authorities. To do so, we refer to the notion of deservingness as a specific frame, 
or discursively constructed concept, that individuals and groups can use, strategically or not, to present their actions and justify their position (Chauvin and Garcés-Mascarenas, 2014). Our central argument is that the injunction to deservingness creates a space in which migrants not only perform strategically what they think is expected from them by state representatives, but also invoke and use the deservingness frame more widely, outside of state interactions, through narratives in which lines of distinction between the 'deserving' citizen and the 'undeserving Others' are prominent.

Through the focus on the distinction between the 'deserving' citizens and the 'underserving' Others, we aim to contribute to the broader reflection about the "inclusive/exclusive logic of citizenship" (Tyler and Marciniak, 2013: 146; Brubaker, 1992). By nature, citizenship is both an instrument of inclusion into a system of rights and a boundary which is "designed to fail specific groups and populations" (Tyler 2010). We explore this dynamic through the focus on its exclusionary logic. In this regard, we follow Sayad (1999), who shows how the analysis of migrants' experience is a way to explore 'pensée d'Etat' and the exclusionary nature of citizenship. Recent studies that have analysed how migrants relate to this exclusionary logic have tended to focus on how they contest and disrupt it. This is the case in particular of the literature that relies on the concept of "act of citizenship" (Isin and Nielsen, 2008), and which analyses migrants' protests as "moments of rupture" (McNevin, 2007; Nyers, 2008; Squire, 2011). However, research is still needed on how migrants can endorse and actively reproduce exclusionary processes. We aim to contribute to the broader reflection on the exclusionary logic of citizenship by analyzing how the citizenship 
test can act as a "disciplinary power", a "technique of the self" (Foucault, 2009; Löwenheim and Gazit, 2009; Turner, 2014) through which migrants can themselves become active agents of reproduction and reinforcement of this logic. In other words, we aim to analyse how migrants can themselves become agents of 'pensée d'Etat' (Sayad, 1999).

This article also aims to contribute to the growing literature that analyses citizenship 'from below' (e.g. Colombo et al., 2011; Leitner and Ehrkamp, 2006; Miller-Idriss, 2006; Sredanovic, 2014), and more specifically narratives about the naturalization process (Byrne, 2014; Fortier, 2013; McGregor and Bailey, 2012; Sayad, 1993). As we will show, the distinction between the 'deserving' citizen and the 'underserving Others' that emerges from our study reflects recent changes in conceptions of citizenship in the UK as well as in other European countries that have adopted the citizenship tests. We will argue that when migrants endorse and use the deservingness frame, this reflects the broader definition of citizens as selfgoverning 'responsible', 'productive' and 'trustworthy' subjects (Huysmans, 2014; Soysal, 2012; Turner, 2014; Walters, 2004).

We draw on qualitative data collected in a research project on the British case. This project is based on 158 in-depth interviews with migrants preparing for the test or having taken the test in two different cities in England (Leicester and London). For the analysis developed in this paper, we explore their experiences with particular reference to how they relate to the idea of 'deservingness'. We have interviewed migrants who: are considering entering the test process; have gone through the process and have passed the test; have gone through the process 
and failed the test; are in the preparation process; have just taken the test. Our sample is composed of participants with different migration trajectories, social backgrounds, nationalities, and personal characteristics: we interviewed participants from 39 nationalities, ranging from less than a year-over 20 years in the UK (the average was 9.8 years), and a variety of legal statuses (e.g. UK citizens, EU citizens, Indefinite Leave to Remain (ILR), applying for ILR). To capture different experiences of the citizenship test, we selected nationalities that have low pass-rates for the test, for example Bangladeshi, whose pass-rate was $44,3 \%$ between 2005 and 2010 (Ryan, 2010), and we also included nationalities that have higher pass-rates, for example Polish, whose pass-rate was $87,5 \%$ in the same period, or Canadians, whose pass-rate was 96,9\% (Ryan, 2010). We accessed participants primarily through migrant advocacy and community organisations ${ }^{3}$, colleges providing language training and snowball sampling. The interviews were conducted from April 2014 to March 2016. ${ }^{4}$ These interviews were complemented with nine interviews in a pilot study as well as informal discussions and interviews in the course of the study with organizational and local authority representatives that were involved in the citizenship test process.

In the course of the interviews, a majority of our participants (94 out of 158) drew lines of distinction between the 'deserving' citizens and the 'underserving Others', in particular when they were asked questions about their own experience of the Life in the UK Test. The use of these distinction narratives can be observed across all demographic characteristics (age, gender, socio-economic background, countries of origin), places (London and Leicester) ${ }^{5}$, and organisations in which 
the fieldwork has been conducted. It is however important to specify that our respondents did formulate different types of positions - even contradictory ones - in relation to the citizenship test, and sometimes in the same interview. Some participants could for example endorse the citizenship test as an instrument of distinction between 'deserving' citizens and 'undeserving Others' but criticize its content or the fact that it was used to control borders (see also Byrne, 2014; McGregor and Bailey, 2012). We explore these other positions and how they relate to each other elsewhere (reference to be added). In this paper, we analyse specifically how a majority of our participants use the notion of deservingness to endorse the idea of the test, and we focus in particular on the interviews in which this narrative is prominent. ${ }^{6}$

In the first section of this paper we will show how, from a theoretical point of view, the definition of citizenship through the deservingness frame relates to narratives of distinction among migrants. Drawing from our empirical analysis, we will then show that three forms of distinction can be observed based on: values of trust and respect; specific forms of social and cultural capital; values of commitment and honesty. These three distinctions reflect public discourses around citizenship and immigration as well as how the test is conceived and managed by state representatives. At a broader level this analysis will show how these distinctions reflect the on-going construction of a neo-liberal and ethos-based citizenship, illustrating thus how migrants can use and actively enforce the 'pensée d'Etat' (Sayad, 1999). 
The deservingness frame and migrants' experiences of the "journey to citizenship"

For the migrants who go through the naturalization process, the citizenship ceremonies are one of the most significant and symbolic steps of the so-called "journey to citizenship". In these ceremonies, a representative of the state delivers a speech before migrants are asked to take the oath and pledge. They are then given a certificate (as well as a medal or a coin in many cases), which makes them officially British citizens. In an interview, an official who is involved in the organization of these ceremonies in a London borough explains the nature of the speech that he delivers to the new citizens:

"I encourage them to involve in various things, I create an awareness of things of what is available in the borough, the history of the borough where we are proud of our diversity and our citizens and they should integrate, (...) and they may come from a different culture, a different background, different environment so they should respect the law of this land and the opportunities.

When I say new home you are coming to a big family is a British family. That family has great values. That is democracy, justice, peace, liberty, equality and freedom and I also understand that a people have their personal and cultural values so you want to see how much they can bring out and share to the family and enjoy the privileges and the key thing is that they should feel proud to be in a big family and tell their children and grandchildren how they have been welcomed."7 
In this description, our respondent argues that citizenship is granted to migrants who can show that they understand and endorse a set of "great values". Speaking solemnly in the name of the state and of "the People of the United Kingdom", he welcomes new citizens in the "British family" and defines at the same time the substance of this family. The presentation of the naturalization process as a form of (conditional) adoption into a "family" echoes recent studies which analyse these ceremonies as "rituals" 8 and which focus on the symbolic dimension of these events (Byrne, 2012; Fortier, 2008; Mazouz, 2012). These studies show that citizenship ceremonies define a narration of the nation that symbolically distinguishes between the good citizens (those who are part of the ceremony) and the 'failed' citizens (the migrants who do not become citizens). At a more general level, these citizenship ceremonies, like the different steps that migrants have to go through to become British citizens, are a ritual through which state authorities demonstrate their "conditional hospitality" (Derrida, 1999; Byrne, 2012): through law enforcement that regulates the mobility and the rights of migrants, the state provides access but also reserves the right and power of the host over the guest, defined as the "other".

With the citizenship tests and ceremonies, it can be argued that the state's conditional hospitality is guided by principles of deservingness: to become a citizen or to be allowed to stay in the territory, migrants need to prove that they deserve to be included. In the words of the London official that we interviewed, those who are about to become citizens must be ready to endorse the "values" of the "British family". They should even show feelings of "pride" to be in this family, 
suggesting thus that this endorsement includes a set of symbolic values that goes beyond a formal agreement.

As we will develop below, the injunction to deservingness is visible in the public debates that surround the citizenship tests and ceremonies in the UK and in other countries. The political imaginary around these issues clearly links access to citizenship to the notion that migrants have to prove their ability and willingness to be 'good citizens' (Fassin and Mazouz, 2007; Schinkel and Van Houdt, 2010). This injunction can be also observed in the ways the whole naturalization process is organized: it is made of administrative hurdles and bureaucratic complexities that migrants have to prove they are able to navigate (Kostakopoulou, 2010; Suvarierol and Kirk, 2015). However, it is important to note that the public debates surrounding the citizenship tests and ceremonies are also characterized by uncertainties: there is a lack of clear definition of who the 'good citizen' is (Shohamy, 2006). In fact, the notion that citizenship has to be earned or deserved is generally based on a loose definition of general values and principles, which can be interpreted in different ways by the local authorities and organisations that are involved in the citizenship test process (Kiwan, 2008; Ryan, 2008). The same can be said about the ways the naturalization process is concretely organized: because of its complexities, constant changes, and the multiplicity of actors involved in it, there is a general uncertainty for migrants about what the "journey to citizenship" concretely entails, and there is variation across different places (Van Oers, 2013).

At a more general level, the notion of deservingness can be linked with the enforcement of a neo-liberal understanding of citizenship (Brown 2003; Hindess, 
2002; Rose 1999) in which subjects are constructed as 'responsible' citizens. The subject of the test process is constructed as actively partaking in a set of established strategies through which they will be responsible and improve themselves (Soysal, 2012; Turner 2014). In this form of citizenship, the 'good citizen' is defined as the model neo-liberal subject who "strategizes for her/himself among various social, political and economic options, not one who strives with others to alter or organize these options" (Brown, 2003). From a similar perspective, the injunction to deservingness can also be related to the enforcement of citizenship's boundaries on the basis of moral values and "ethos", what Nikolas Rose identifies as 'etho-politics':

"By etho-politics I mean to characterize ways in which these features of human individual and collective existence-sentiments, values, beliefs-have come to provide the 'medium' within which the self-government of the autonomous individual can be connected up with the imperatives of good government" (Rose, 1999: 477).

Recent studies have analysed the significance of the injunction of deservingness in naturalization or legalization processes, and in particular the consequences of this injunction on migrants' strategies of self-presentation when they relate to state representatives. Fassin and Mazouz (2007) and Mazouz (2012) have thus shown that the nature of the naturalization process in France leads migrants to show their attachment to what they perceive as the dominant cultural norms. This process leads them to distinguish themselves symbolically from those "who don't 
want to integrate" and "who speak bad French" (Mazouz, 2012: 148). Byrne (2014) and Fortier $(2008,2013)$ show that, although they can be sometimes critical of dominant discourses around integration, migrants strategically present themselves as 'deserving' and emotionally engaged in the course of their naturalization process. Looking at the language requirements in the British case, Khan (2013) shows how migrants are able to reproduce dominant monolingual discourses for the purpose of the naturalization process, but also use bilingual resources to navigate through the process. In the same sense, work by Berger (2009) and Villalon (2010) shows how women who apply for legalization through the Violence Against Women Act in the US present themselves through narratives that fit with what is expected by state representatives (Menjivar and Lakhani, 2016; see also Coutin, 2000; Nicholls, 2013; Chauvin and Garcés-Mascarenas, 2014). As shown by Menjivar and Lakhani (2016) in the American case, the reproduction of dominant discourses on deservingness has transformative effects: in the prospect of their legalization, migrants undertake personal and social transformations in order to fulfill their position of deserving citizens, and also broader personal life projects.

More generally, empirical studies show that migrants' views on citizenship are also influenced by their encounters with local authorities and the state apparatus, as well as by broader media and political discourses on citizenship, whether a citizenship test is in place or not. Thus, in her study on Italian and migrant factory workers, Sredanovic (2014: 684) shows how, in contrast with Italian workers, migrants have assimilated the "integrationist approach" of local authorities and endorsed the idea of cultural requirements to access citizenship (even if 
citizenship tests do not exist in Italy). Also, as shown by Colombo et al.'s (2011: 340) study on children of immigrants in Italy, migrants' experience of hurdles in a bureaucratic state system led them to consider the nation-state as "the central reference for the definition of criteria for inclusion and exclusion" (even if they also develop ideas of fluid and multiple belongings in parallel) (see also Leitner and Ehrkamp, 2006 on the German and US cases). This leads us to specify that migrants' perspectives on citizenship are shaped by their experience of the citizenship test, and also more generally by their (situated) experience of local state authorities as well as their reception of broader media and political discourses on citizenship.

Drawing on these perspectives, we explore how migrants who go through the naturalization process perform processes of distinction between the 'deserving' migrant and the 'undeserving Others'. In the following sections we show how these migrants refer to the dominant discourse on deservingness and use what they understand to be its values and symbols in order to construct themselves as agents who "contribute to the community of values" (Anderson, 2013). For that, they enter into a zero-sum logic. To be included they draw a line between themselves and the undeserving 'Others' as defined by a neo-liberal and ethosbased understanding of citizenship. This logic, is embedded in the experience of the Life in the UK test as well as in encounters with local and national state apparatus and in political and media discourses on citizenship.

\section{A distinction based on values of trust and respect}


First, the interview analysis shows that the majority of our participants perform a narrative that is in line with the state's discourses and category construction on immigration and citizenship. To analyse this form of distinction, we must first explore further the ideas that were mobilized by state's representatives to justify the introduction of the citizenship test. For that we can refer to Walter's notion of "domopolitics" (Walters, 2004), and more generally to the process of securitization of citizenship in political and media discourses in the last decades (Bigo, 2002; Huysmans, 2014).

Analysing the White Paper that inspired new British immigration and integration policies in 2002 (and which led to the introduction of the citizenship test in the UK) ${ }^{9}$, Walters (2004) argues that these new policies are based on "a reconfiguring of the relations between citizenship, state, and territory" (Walters, 2004: 241). To grasp this reconfiguration, he proposes the notion of domopolitics. This concept implies that citizenship is constructed through the aspiration to "govern the state like a home", "a safe, reassuring place, a place of intimacy, togetherness and even unity, trust and familiarity" which contrasts with the risks of a "chaotic outside" (Walters, 2004: 241).

From this perspective, the citizenship test is presented by state authorities as an instrument of domopolitics: it grants citizenship like a sort of invitation to "home", to those who can be "trusted", with whom there are some affinities, those the state can make sure don't bring insecurity (Huysmans, 2014). ${ }^{10}$ Access to citizenship is thus not conceived as a right, but more as something migrants should deserve on the basis of the proof of good behaviour (someone who respects "our values, our 
way of life" Walters, 2004: 247). The idea of domopolitics relates to Rose's (1999) definition of 'etho-politics': boundaries of inclusion and exclusion are based on sentiments, values, and beliefs (see also Brown, 2009).

Our interviews show that the majority of our participants perform a discourse that reflects aspects of these dominant conceptions of citizenship. These migrants insist on showing their 'good will' and their own morality, and they develop the idea that values of respect, law abidingness, and being trustworthy need to be used to distinguish between 'deserving citizens' and 'undeserving Others'. Thus, they perform their 'deservingness' by criticizing those 'who don't want to learn', who 'don't want to integrate', and more generally those who don't adhere to the ethos of the 'safe haven'.

This type of distinction is for example visible in the interview of a woman in London, from a Middle-Eastern country, and now a British citizen, who has been in the UK for 18 years. In this interview, she endorses the idea of the citizenship test and, reflecting the trend towards securitization of citizenship, she argues that the utility of the test is to select the people who "deserve to be here" 11 and in particular those who can show values of "respect":

“A lot of people they don't deserve it to get a British passport and they doing something absolutely opposite, something wrong a lot of you know terrorist and things like this and that's why if they make it much harder the only people who pass it they deserve to be here. (...) I am foreigner in this country but as far as you become British, you have to respect the law" (Interview 3, London, May 2014) 
Later in the interview, she goes further and produces a discourse that clearly resonates with the notion of domopolitics (the idea of the "second home") and which uses the idea of "good citizenship" in order to distinguish herself from 'undeserving Others':

"If I see [name of the country] people doing something wrong to this country, because they are gonna put my country's name in a bad way but definitely I am not angry and I say how did they give you a British passport, you promise you gonna be good citizenship. This is your second home you gonna have to look after it" (Interview 3, London, May 2014)

The idea that those who apply for citizenship should prove their "good citizenship" is also underlined in an interview with a person of Eastern-European origin who has been living in the UK for 24 years and who recently became a British citizen. Her response to the question of why she thinks the government introduced the Life in the UK test refers to the idea that people have to demonstrate a certain set of values (their "quality") as well as their "motivation" to become a citizen:

"It's not my place to judge but I think the Government introduced because to find out what quality of a person would you have in mind, how you going to contribute to the community something like this needs to be gained, the motivation why do you want to become of a citizen, what you want to enhance the community with you know with this kind of questions need to be gathered out of this application of test, otherwise we know people misusing their citizenship in many ways and 
through that test can eliminate people who actually don't deserve it so that would probably be it." (Interview 31, London, February 2015)

The general suspicion towards those who don't adhere to the values attributed to British citizenship (to use the words of the interviewee, those who "misuse their citizenship") is common among participants who perform a narrative of distinction. This suspicion shows that they situate themselves symbolically among those who are able to "judge" on the basis of the values attributed to British citizenship. For example, just after saying that "it's not my place to judge", this participant implies that it is possible to identify those who "actually don't deserve" citizenship. The use of the word "actually" is important here as it implies that she knows the "actual" (clear and objective) criteria that distinguish the "deserving citizen' from the 'undeserving Others'. In doing so, she is telling us that she integrated and even represents these values (without specifying precisely what they are); she situates herself symbolically among the deserving citizens, those who know, those who can judge. In other words, she clearly identifies herself as someone who can be 'trusted', reflecting thus the moral values attached to the notion of domopolitics. A similar process of distinction is visible when we analyse participants' perceptions of the specific knowledge and skills that are required to navigate through the naturalization process.

\section{A distinction based on social and cultural capital}

The second type of distinction that emerges from our interviews relates to the 
meaning given to the citizenship test and to the type of knowledge associated with it. In contrast with the first type of distinction (which relates to boundaries based on moral values), this form of distinction is closer to the processes analysed by Bourdieu (1979): what is at stake is the symbolic demonstration of social status and the ability to use certain forms of knowledge and skills (in particular linguistic knowledge and cultural capital). Migrants who perform this type of distinction describe the citizenship test as a linguistic and cultural performance of the candidates to public authorities and they adhere to the idea that those who can't 'perform' in certain ways do not deserve to become citizens. In doing so, they propose a vision of citizenship which is in line with the broader neo-liberal conception of citizenship (Soysal, 2012). The linguistic and cultural performance they refer to is the result of individual strategies of "self-improvement" (Turner, 2014), and a failure to pass the test is presented as an individual responsibility especially as success is linked to learning which everyone is perceived to be able to do. This neo-liberal conception of citizenship can be observed in the way the citizenship test has been presented by policy-makers when it was introduced (Schinkel and Van Houdt, 2010). Thus, as shown by Turner (2014: 335), the implementation of the citizenship test in the UK is based on the principle that "testing strategies ask for active participation; for subjects to pay, to learn, to 'better' themselves. In doing this, they ask for the migrant-subject to work on themselves; be responsible, to 'improve', do what is necessary". This idea is also underlined by Suvarievol and Kirk (2015: 262) in the Dutch case: they argue that "civic integration has become a manifestation of neoliberal ideology, whereby the migrants are responsible for their own integration, and the market is the ideal tool to facilitate responsibilized integration". 
In their description of the citizenship test, migrants give a specific meaning to it: they present it as a condition to access social status. It is a 'rite of passage' that will enable them to access different elements that are associated with a higher and more stable social status: employment, access to social services, mobility, security, stability, a possibility to invest in the future. At a more general level, access to citizenship is often presented as a way to gain "normality": they argue that people will consider them as "one of them" and will "stop asking them questions" once they become a citizen. This is for example the case of a Latin-American participant who has been living in London for five years. She argues in the interview that, even if it will not change her residence status in a fundamental way, having a British passport will change how people will "treat her" in her interactions with state representatives and in the job market:

"Interviewer: Are there any examples where you think, if I had a British passport now, it would make my life easier?

Participant: Yeah, we have a problem with the council and I see because my husband British think more things the attention than me because I am not. Interviewer: So you can kind of sense it when they talk to you. Participant: Yeah I can see the difference how they treat him and how they treat me. As well once I went to get an interview job and because I didn't have the passport they were even if I have the leave to remain I have the right to work it was like that, not enough." (Interview 23, London, November 2014) 
The association of access to citizenship with a higher and more stable social status leads many of our interviewees to refer to the deservingness frame. They formulate the idea that access to citizenship (and so the social status attached to it) can only be granted to those who can prove their ability to demonstrate the specific knowledge which is associated with the citizenship test. Although they can be critical of the complexities of the citizenship test, they relate to the general idea that access to citizenship is based on the demonstration of certain abilities and that the test is a way to effectively measure them. ${ }^{12}$ Thus, in relation to the language component of the naturalization process, many interviews reflect the idea that a 'deserving' citizen is a citizen with a good level of English. This is for example the case for a participant originally from a Central-Asian country, who has been living in the UK for seven years. He argues that having a good level of English is a condition for living in the country:

"Interviewer: Do you think, what do you think about doing a citizenship test? Do you think it's a good thing or...

Participant: I think it's a very good thing because I have friends and they have British passport and they can't speak English, I think it's very good to have a test and...

Interviewer: To help them with the English?

Participant: English and if you live this country you have to understand English and you have to speak English, you shouldn't take with you interpreter or something." (Interview 32, Leicester, February 2015) 
Interestingly, this specific narrative of distinction from the 'undeserving Others' (those who can't speak good English) shows that the citizenship test is not conceived as a first step that could help people in their integration process; it is conceived as a way to justifiably exclude those who can't meet certain standards. This observation about the question of language can be extended to the other forms of knowledge that are associated with the content of the citizenship test and with citizenship more generally. This is for example illustrated in the interview with a participant, originally from Northern-Africa, who has been living in the UK for eight years. When asked his opinion about why the citizenship test was introduced in the UK, he insists that people "must understand" and he argues that this is "right". He goes further and argues that the knowledge is needed not just to pass the test, but really to demonstrate that those who apply for citizenship fully participate and 'deserve' citizenship:

"This is good thing. You know people must understand little bit English and people must understand about the country so if you hold like British passport, if you don't speak nothing it's not right (...)." (Interview 10, Leicester, September 2014).

In the same perspective, the link between the frame of the deserving citizen and certain forms of cultural capital is illustrated well in this interview with a man from a West-African country, who has been in the UK for eight years. He argues that there are "good reasons" for which the government introduced the citizenship test and that he "agrees with that". He insists in particular on the idea that migrants must prove their ability to "participate": 
"If you want to live in a place and participate in whatever activities they are doing, you have to know some basic things." (Interview 1, Leicester, May 2014).

When asked why he thinks some people choose not to take the test, he underlines what he believes are cultural markers of his own position in order to distinguish himself from others:

“Well I think it's because most people are not really educated to pass the test. I must be very honest with you. The book is written in a very simple English. Anyone who is educated, you will read it and understand it. But when you take the test, the people who set up tests, they are professionals. I took the test, I know what it is. You really have to be educated to pass." (Interview 1, Leicester, May 2014)

As these interviews illustrate, migrants perform a narrative of distinction according to which access to social status (which is associated with citizenship) is attached to certain forms of linguistic knowledge, cultural capital, and a general 'savoir faire'. In doing so, they do not object to the more general processes of exclusion of those who can't demonstrate the specific forms of social and cultural capital that are required in the course of the naturalisation process. In line with the general notion of neo-liberal citizenship, their discourse symbolically excludes those who can-not demonstrate these specific forms of capital. 


\section{A distinction based on values of commitment and honesty}

The last process of distinction relates to the notion that citizenship has to be deserved in a literal sense. Many of the participants who perform narratives of distinction endorse the general idea that those who seek access to citizenship should demonstrate the efforts that they make to go through the naturalization process. In doing so, they associate access to citizenship with values of commitment and honesty, and they differentiate themselves from the figure of the migrant who would 'take advantage of the system'. This specific narrative of distinction indicates a more general conception of citizenship which is in line with the ethos-based and neo-liberal transformations of citizenship in recent decades. This distinction relates to moral values (trust, commitment and honesty in particular) which converge with notions of responsibilisation and selfimprovement. The individual strategies of self-improvement that lie at the core of the neo-liberal understanding of citizenship become thus associated with moral values that relate to a loosely defined "way of life" (Anderson, 2013). In other words, access to citizenship - as an element of self-government - is conceived as both a strategic performance and a moral stance.

This form of distinction is particularly visible when participants explain the different steps of the process they have to go through to become British citizens. When asked about the practicalities of the naturalisation process, participants describe an intimidating experience. The interviews show that they face a complex, long and impersonal process made up of bureaucratic obstacles, a series of tests, multiple steps, different agents, etc. When describing this process, 
participants imply that it is not only their knowledge of life in the UK and of English language that is tested. It is also their ability to deal with bureaucratic hurdles (individually or through their networks), and at a more general level, their confidence and their patience. It is also their ability to 'demonstrate' that they can navigate this complex process, in particular through the accumulation of paperwork and through their social networks (for a similar argument, see Chauvin and Garcés-Mascarenas, 2014). This is visible in an interview with a NorthernAfrican migrant who has been living in the UK for eight years. The amount of details that he describes to present the naturalisation process, and the multiple references to the support of the Sudanese community, show that access to citizenship is perceived as a long, complex and uncertain process that can only be navigated through the use of social skills and perseverance:

"If you apply now, you lose your money. You have to wait till June and then come back so I left, I been till June so that time is I think it's been about two months and then I been filling another forms and then our community, they signed it for me and then I made appointment with the council hall and I been there they check it everything they said ok so that's time they took everything copy for my document and they say ok, we will send it so when they send it they call me, they told me, we sending your application today and they gave me everything and then even they wrote to me to say the receive it and got the money, just wait after 6 months if you didn't get anything, you can call us." (Interview 10, Leicester, September 2014)

The presentation of the "journey to citizenship" as a long and difficult process is also visible in how our interviewees present the content of the test and of the 
language requirements. As a matter of fact, many of them explain that the test is difficult to pass and that many people have to take it several times. ${ }^{13}$ Thus, in the same interview, the participant describes the difficulties of the test, implying again that perseverance is needed to prepare for it:

"Yes it is very difficult, very, very, very difficult, even now my wife she trying even now she not passing, she just practicing, she didn't try to do the book, the test, just she trying to understand everything, improve everything so it is very difficult. Very very difficult" (Interview 10, Leicester, September 2014)

From this perspective, many participants perform a narrative of distinction between those who 'make the effort' to prepare for the test and those who don't. This idea is thus expressed by a participant who is originally from Central-Asia and who has been living in the UK for six years. When asked what he would change in the content of the test, he underlines the difficulties of the test, but he also deplores that some people are "cheating", reflecting a divisive public discourse that positions some migrants as fraudsters. He then argues that some people decide not to do the test because they "just give up":

"Yes I know that people as well who said I don't want to do to do the test because it's very difficult to pass it and because they don't know proper English. They just doing it like Entry Level 2. They see the book and they say I can't do it. The give up so still the other side they wish to pass it but no reason they have to do it. Can't do it." (Interview 26, Leicester, January 2015) 
In the course of the interviews, these participants are keen to show that, in contrast with the people who "cheat" or "give up", they adhere to values of commitment and honesty. Thus, this last interviewee explains later in the interview that he finds the content of the citizenship test difficult, but that he is "working hard", in particular in the language courses, explaining thus his willingness to learn.

From a similar perspective, an Eastern-European participant who has been living in the UK for nine years argues that migrants need to demonstrate their "effort" and their "work", which becomes ultimately a proof of their "commitment":

Yes, but it shows commitment it's not everyone's entitled to everything, you should do something to get it. So yeah I didn't look in detail, I didn't look at the test but I know if I wanted to do it I'll just get a book, practice and then sit it and probably pass it so it's not like, I don't see it as a major issue." (Interview 47, Leicester, February 2016)

In this extract, the reference to the notion of "commitment" is crucial as it denotes the general meaning given to the citizenship test. According to this participant, the values of commitment that migrants have to demonstrate throughout the citizenship test process are indicators of their commitment to British society more generally. He argues thus later in the interview that: "if someone wants to be a citizen of a certain country, (...) I think they should demonstrate that they actually want it." 
The same type of distinction can be observed when participants are asked whether some groups have more difficulties than others to pass the test. Some of the interviewees argue that those who have been granted refugee status would have an easier process, regretting thus that the naturalization process can be "unfair". This is for example the case of a participant who is originally from a WestAfrican country and who has been living in the UK for ten years. She argues that refugees would have an advantage in the system because, legally, they don't have to wait five years to apply for an Indefinite Leave to Remain and then citizenship:

“I don't see why it's good to do the Life in the UK but what I feel like is if people come why and how are like asylum seekers, they can start their life straightaway because they can start to learn this straightaway, they don't need to wait, wait, wait years before their life starts. I feel like constant waiting because somebody wait 10 years then they say you need to go to school, you understand? The brain is like waiting!" (Interview 11, London, August 2014)

As these interviews illustrate, participants who use deservingness frames and narratives of distinction are keen to demonstrate their willingness to prepare for the test and to become citizens. The figure of the migrant who 'takes advantage of the system' or who does not demonstrate his good will (and commitment) is used by way of contrast, so they can position themselves as deserving citizens. This last process shows again how these participants reproduce and reify symbolic boundaries that are by nature exclusionary, in particular through the use of markers of distinction that relate to perceived fundamental individual characteristics (in this case values of commitment and honesty). 


\section{Conclusion}

The analysis of migrants' experiences of the British citizenship test shows the nature of the deservingness frames that they use to distinguish between the 'good citizens' and the 'undeserving Others'. By referring to the values and resources that are associated with the figure of the 'deserving citizen', a majority of the migrants we interviewed performed narratives that reflect the nature of public authorities' "conditional hospitality" (Derrida, 1999) as well as the broader "inclusive/exclusive logic of citizenship" (Tyler and Marciniak, 2013; Brubaker, 1992; Sayad, 1999). At a more general level, the analysis shows that these narratives of distinction reflect recent changes in the ways citizenship is defined in public discourses and managed by state representatives. In particular, the narratives we have analysed in this paper reflect the general trend towards a neoliberalisation of citizenship and the more specific construction of a "domopolitics" based on moral values and ethos (Hindess, 2002; Walters, 2004).

This analysis of citizenship 'from below' shows thus that discourses and laws around citizenship and migration do not only affect migrants' strategies of selfpresentation when they face state-representatives. They also affect, more fundamentally, the logics through which migrants position themselves in society (Menjivar and Lakhani, 2016). As a matter of fact, the use of the deservingness frame shows how the citizenship test creates a logic of 'Us and Them' (Anderson, 2013), which leads to processes in which migrants, because they are suspected 
not to be "firmly established in the community of value", have to "endlessly prove themselves, marking the borders, particularly of course by decrying each other" (Anderson, 2013: 15). The narratives analysed in this paper show that, through the endorsement of the deservingness frame and the 'Us and Them' logic that results from it, migrants recognize that they are the targets of "exclusory techniques of government" (Turner, 2014: 335) but, at the same time, they become agents that can symbolically enforce the 'pensée d'Etat' (Sayad, 1999). The analysis of this paradoxical position converges with Turner's (2014) and Löwenheim and Gazit's (2009) idea that the "inclusive/exclusive logic of citizenship" (Tyler and Marciniak, 2013; Brubaker, 1992) that is asserted and reified by the citizenship test is not only a top-down process, but also a "technique of the self" (Foucault, 2009), a practice of disciplinary power that goes across society.

\section{References}

Agamben, G. 1998. Homo Sacer: Sovereign Power and Bare Life. Stanford: Stanford University Press. 
Anderson, B. 2013. Us and Them? The Dangerous Politics of Immigration Control. Oxford: OUP.

Bigo, D. 2002. "Security and Immigration: Toward a Critique of the Governmentality of Unease", Alternatives 27(1), pp. 63-92.

Berger, S. 2009. "Un-Worthy: Latina Battered Immigrants under VAWA and the Construction of Neoliberal Subjects." Citizenship Studies 13 (3): 201-17.

Bourdieu, P. 1979. A Social Critique of the Judgement of Taste. Harvard University Press.

Brown, W. 2003. "Neo-liberalism and the End of Liberal Democracy." Theory and Event 7(1)

Brown, W. 2009. Regulating Aversion: Tolerance in the Age of Identity and Empire. Princeton: Princeton University Press

Byrne, B. 2012. "A local welcome: Narrations of nation and citizenship in UK citizenship ceremonies." Citizenship Studies, 16(3-4): 531-544

Byrne, B. 2014. Making Citizens. Politics of Identity and Citizenship. Basingstoke: Palgrave Macmillan. 
Chauvin, S. and B. Garcés-Mascareñas. 2012. "Beyond Informal Citizenship: The New Moral Economy of Migrant Illegality." International Political Sociology 6 (3): $241-59$

Colombo, E., Domaneschi, L. \& Marchetti, C. 2011. "Citizenship and multiple belonging. Representations of inclusion, identification and participation among children of immigrants in Italy." Journal of Modern Italian Studies 16(3): 334-347.

Coutin, S. B. 2000. Legalizing Moves: Salvadoran Immigrants' Struggle for U.S. Residency. Ann Arbor: University of Michigan Press

Damsholt, T., 2008. The sound of citizenship. Ethnologia Europea, 38 (1): 56-65

Derrida, J. 1999. “Hospitality, Justice and Responsibility: A Dialogue with Jacques Derrida." In R. Kearney and M. Dooley (eds.), Questioning Ethics: Contemporary Debates in Philosophy. Routledge: 65--83

Fassin, D \& S. Mazouz. 2007. “Qu'est-ce que devenir français? La naturalisation comme rite d'institution républicain" [What is it to become French? Naturalization as a rite of Republican institution] Revue française de sociologie 48(4): 723-750 
Foucault, M. 2009. Security, Territory and Populations: Lectures at the Collège De France. Basingstoke: Palgrave.

Fortier A-M. (2008) Multicultural Horizons: Diversity and the Limits of the Civil Nation. London: Routledge

Fortier, A-M. 2013. "What's the big deal? Naturalisation and the politics of desire.” Citizenship Studies 17(6): 697-711

Hajjat A. 2010. “Port du hijab et 'défaut d'assimilation'. Étude d'un cas problématique pour l'acquisition de la nationalité française", Sociologie 4(1): 439455.

Hindess, B. 2002. “Neo-Liberal Citizenship.” Citizenship Studies 6 (2): 127-143.

Home Office. 2011. Life in the UK Test: A Journey to Citizenship. London: TSO

Huysmans, J. 2014. Security Unbound. Enacting Democratic Limits. Abingdon: Routledge

Isin, E., and G. Nielsen. 2008. Acts of Citizenship. London: Zed Books.

Joppke, C. 2007. "Beyond National Models: Civic Integration Policies for Immigrants in Western Europe." West European Politics 30 (1): 1-22. 
Khan, K. 2013. Becoming British: a migrant's journey. Unpublished PhD Thesis, University of Birmingham

Kiwan, D. 2008. “A Journey to Citizenship in the United Kingdom.” International Journal of Multicultural Societies 10(1): 60-75.

Kostakopoulou, D. 2010. "Matters of Control: Integration Tests, Naturalisation Reform and Probationary Citizenship in the United Kingdom." Journal of Ethnic and Migration Studies 36(5): 829-84.

Leitner, H \& Ehrkamp, P. 2006. “Transnationalism and Migrants' Imaginings of Citizenship." Environment and Planning 38(9): 1615-163.

Löwenheim, 0. and 0. Gazit. 2009. "Power and Examination: A Critique of Citizenship Tests." Security Dialogue 40(2): 145-167

Mazouz, S. 2012. “'Une faveur que vous a accordée la République’ Comment la naturalisation se mérite" in D. Fassin and J.S. Eideliman (eds.), Economies Morales Contemporaines. Paris: La Découverte: 137-154

MacGregor, S. \& Bailey, G. 2012. "British citizen or other? Reflections on New Labour's reforms to the UK citizenship process." British Politics 7(4): 365-388. 
McNamara, T., and Roever, C. 2006. Language Testing: The Social Dimension. Oxford: Blackwell Publishing

McNevin, A. 2007. "Irregular Migrants, Neoliberal Geographies and Spatial Frontiers of 'the political'." Review of International Studies 33 (4): 655-674.

Menjívar, Cecilia and Sarah M. Lakhani. 2016. "Transformative Effects of Immigration Law: Immigrants' Personal and Social Metamorphoses through Regularization." American Journal of Sociology 121(6): 1818-1855

Miller-Idriss, C.. 2006. "Everyday Understandings of Citizenship in Germany." Citizenship Studies 10(1): 541-570

Nicholls, W. 2013. "Making undocumented migrants into legitimate political subjects: A comparison of France and the United States." Theory, Culture and Society 30(3): 82-107

Nyers, P. 2008. "No One is Illegal: Between City and Nation." In Acts of Citizenship, edited by E. Isin and G. Nielsen, 160-181. London: Zed Books.

Rose, N. 1999. "Inventiveness in politics." Economy and Society 28(3): 467-493.

Ryan, B. 2008. “Integration requirements: a new model in migration law.” Journal of Immigration Asylum and Nationality Law 22(4): 303-16. 
Sayad, A. 1993. "Naturels et naturalisés." Actes de la recherche en sciences sociales 99(1): 26-35.

Schinkel, W. and F. van Houdt. 2010. "The double helix of cultural assimilationism and neo-liberalism: Citizenship in contemporary governmentality." The British Journal of Sociology 61(4): 696-715.

Shohamy, Elana Goldberg, 2006. Language Policy: Hidden Agendas And New Approaches . London: Routledge

Soysal, Y. 2012. “Citizenship, immigration, and the European social project: rights and obligations of individuality." The British Journal of Sociology 63(1): 1-21

Squire, V., ed. 2011. The Contested Politics of Mobility: Borderzones and Irregularity. Abingdon: Routledge.

Sredanovic, D. 2014. “Culture or taxes? The conceptions of citizenship of migrants and local factory workers in Italy", Citizenship Studies, 18(6-7): 676689.

Suvarierol, S. and K. Kirk. 2015. "Dutch civic integration courses as neoliberal citizenship rituals." Citizenship Studies 19(3-4): 248-266 
Tonkens, E., M. Hurenkamp, and J. W. Duyvendak. 2010. "Culturalization of citizenship in the Netherlands." in A. Chebel d'Appollonia and S. Reich (eds.), Managing Ethnic Diversity after 9/11: Integration, Security, and Civil Liberties in Transatlantic Perspective

Turner, J. 2014. “Testing the liberal subject: (in)security, responsibility and 'selfimprovement' in the UK citizenship test." Citizenship Studies 18(3-4): 332-348

Tyler, I. 2010. “Designed to fail: a biopolitics of British Citizenship." Citizenship Studies 14 (1): 61-74.

Tyler, I., and K. Marciniak. 2013. “Immigrant Protest: An Introduction.” Citizenship Studies 17 (2): 143-156.

Van Oers, R. 2013. Deserving Citizenship. Citizenship Tests in Germany, the Netherlands and the United Kingdom. The Hague: Brill

Villalon, R. 2010. Violence Against Latina Immigrants: Citizenship, Inequality, and Community. New York: NYU Press

Vink, M. P., and G. de Groot. 2010. “Citizenship Attribution in Western Europe: International Framework and Domestic Trends." Journal of Ethnic and Migration Studies 36(5): 713-734 
Walters, W. (2004), “Secure Borders, Safe Haven, Domopolitics." Citizenship Studies 8(3): 237-260

1 These requirements were then extended to those who applied to Indefinite Leave to Remain.

${ }^{2}$ See Chauvin and Garcés-Mascarenas (2014) for a review.

${ }^{3}$ Some of these organisations were more critical of the citizenship test than others, and we could thus observe whether different organizational perspectives were reflected in migrants' views.

${ }^{4}$ The data collected were coded and analysed systematically using Nvivo software. The different positions in relation to the deservingness frame were identified inductively, looking in particular at responses to questions on the perceived usefulness of the test or its difficulty.

${ }^{5}$ As we develop elsewhere (reference to be added), we observe some differences between the cases of London and Leicester in terms of how the test is generally experienced by migrants. This confirms empirical studies that have shown variations related to the interactions with local authorities and the citizenship 
ceremonies (Byrne, 2012; Hajjat, 2010). However, we do not observe notable differences between the cases of London and Leicester when it comes to the use of the deservingness frame.

${ }^{6}$ We acknowledge the inevitable role of performance and social desirability bias in the interviews. For example, we observe that participants that have a higher socio-economic background and that come from Anglophone countries (Canadian or American middle-class migrants living in London) tended to rely less often on narratives of deservingness. We argue that this group had the 'privilege' not to feel obliged to demonstrate their 'good citizenship' during the interviews. Throughout the research process, we have reflected on the influence of power dynamics to consider what participants may have decided to say, not to say, and how to present themselves. In the beginning of each interview, we have explained carefully to our participants that our position and research aims are independent from the Home Office or any state representative that they encounter in their naturalization process as well as from the organisations that helped with the recruitment.

7 Interview in London, December 2013

${ }^{8}$ Many studies have analysed the citizenship ceremonies as "rituals", drawing in particular on Arnold van Gennep's (1909) seminal analysis (Byrne, 2014; Damsholt, 2008). As reminded by Fassin and Mazouz (2007), "rituals" aim to demonstrate a form of belonging (new citizens show their attachment to the group they have just been made part of), but at the same time, they also aim to demonstrate a "separation" from the group of origin (new citizens show that they have become different from foreign nationals). More generally, these ceremonies also reify a distinction between the 'natural' citizens (those who 
were born citizens) and the 'naturalized' citizens (those who have to go through a naturalization process) (Sayad, 1993).

${ }^{9}$ Home Office, "Secure Borders, Safe Haven - Integration with Diversity in Modern Britain", 7 February 2002

${ }^{10}$ It is interesting to note how, in the interview presented above, the state representative giving a speech at the citizenship ceremonies describes the UK as a "home", a welcoming "family" with its "values" and "privileges", giving thus a perfect illustration of how domopolitics translates into official discourse.

${ }^{11}$ She argues elsewhere in the interview that the test should be made harder to screen out those who lack the appropriate values.

12 This echoes Löwenheim and Gazi's (2009) observation that the authority of the state is asserted and reified through the process of examining itself, not so much through the content of the test.

${ }^{13}$ Interestingly, this observation contrasts with the type of distinction analysed in the previous section (based on cultural capital). In this previous distinction process, some participants argued that the test was 'easy for them'. This shows that participants can experience the same aspects of the process in different ways, leading to diverging positions as 'deserving citizens' or struggling with the requirements of the test or even both. At a broader level, this shows that deservingness frames can contradict each other (Chauvin and Garcés-Mascarenas, 2014). 